\title{
Slender-horned gazelle (Gazella leptoceros), a new host for Tricholipeurus balanicus (Phthiraptera: Ischnocera: Trichodectidae)
}

Ciöl Ceylanı (Gazella leptoceros), Tricholipeurus balanicus (Phthiraptera: Ischnocera:

\section{Trichodectidae) için Yeni Bir Konak}

\author{
Bilal Dik², Faiza Marniche², Amel Milla², Houria Benbelcacem² \\ 'Department of Parasitology, Selçuk University School of Veterinary, Konya, Turkey \\ 2Preclinical Zoology, National Veterinary School of El Alia, Algeria, Cezayir
}

\section{ABSTRACT}

This study was performed to provide information on Tricholipeurus balanicus (Werneck 1938) detected on slender-horned gazelles (Gazella leptoceros) (Cuvier 1842). Four slender-horned gazelles kept in the El Hamma Zoological Garden in Algeria were examined for lice in April 2015. Three of the four gazelles were infested with lice; of 37 lice collected from the infested animals, 14 were females, 16 were males, and 7 were nymphs. Lice were mainly found on the back and hind legs of the gazelles. The lice were collected by a forceps, preserved in $70 \%$ alcohol, and cleared in $10 \% \mathrm{KOH}$ for $24 \mathrm{~h}$. Thereafter, they were rinsed in distilled water, transferred to $70 \%$ and $99 \%$ alcohol, mounted on slides in Canada balsam, examined under a binocular microscope, and identified as Tricholipeurus balanicus (Werneck, 1938). To the best of our knowledge, T. balanicus on $G$. leptoceros has been reported for the first time.

Keywords: Tricholipeurus balanicus, Gazella leptoceros, Slender-horned gazelle, El Hamma zoological garden, Algeria

Received: 25.05.2016 Accepted: 22.09.2016

\section{ÖZ}

Bu çalışma Çöl ceylanlarında (Gazella leptoceros) (Cuvier, 1842) tespit edilen Tricholipeurus balanicus (Werneck, 1938) hakkında bilgi vermek amacıyla yapılmıştır. Cezayir'de, El Hamma Hayvanat Bahçesi'ndeki dört Çöl ceylanı Nisan 2015'de bit yönünden incelenmiştir. Inncelenen 4 ceylandan üçü bitle enfeste bulunmuş, enfeste hayvanlardan 14'ü dişi, 16'sı erkek ve 7'si nimf olmak üzere 37 bit toplanmıştır. Bitlere ceylanların özellikle sırt kısımlarında ve arka bacaklarında rastlanmıştır. Bitler bir pensle toplanmış, \%70 alkolde saklanmış ve saydamlaştırılmak üzere \%10 Potasyum hidroksit $(\mathrm{KOH})$ içinde 24 saat bekletilmiştir. Sonra distile su, \%70 ve \%99 alkolden geçirilmiş, Kanada balsamla lam üzerine yapıştııılarak binoküler mikroskopta incelenmiş ve Tricholipeurus balanicus (Werneck, 1938) olarak teşhis edilmiştir. Bu araştırmayla T. balanicus G. leptoceros'dan ilk kez kaydedilmiştir.

Anahtar Kelimeler: Tricholipeurus balanicus, Gazella leptoceros, Çöl ceylanı, El Hamma Hayvanat Bahçesi, Cezayir Geliş Tarihi: 25.05.2016

Kabul Tarihi: 22.09.2016

\section{INTRODUCTION}

The slender-horned gazelle (Gazella leptoceros) (Cuvier, 1842), also known as the rhim or the sand gazelle, is mostly adapted to desert life and can be found in desert areas in North Africa, i.e., Algeria, Tunisia, Libya, and Egypt (1-4).

Today, the genus Tricholipeurus Bedford, 1929 is represented by more than 20 species (5-14). Ledger (15) reported 16 Tricholipeurus species from animals living in the south of Sahara. Until today, no Tricholipeurus species had been reported from $G$. leptoceros.

\section{CASE REPORT}

Four slender-horned gazelles were examined for lice in the zoological garden of El Hamma in Algeria. Three of four gazelles were infested with lice. Thirty-seven specimens, 14 females, 16 males, and 7 nymphs, were collected from the gazelles. Louse specimens were collected from the back and hind legs of the gazelles. They were preserved in alcohol and cleared in $10 \% \mathrm{KOH}$ for $24 \mathrm{~h}$. There after, they were rinsed in distilled water for $24 \mathrm{~h}$ and kept first in 70\% alcohol and then in $99 \%$ alcohol $24 \mathrm{~h}$. They were mounted on

Yazışma Adresi / Address for Correspondence: Bilal Dik E.mail: bdik2005@yahoo.com DOI: $10.5152 /$ tpd.2016.4910

CCopyright 2016 Turkish Society for Parasitology - Available online at www.tparazitolderg.org

CTelif hakkı 2016 Türkiye Parazitoloji Derneği - Makale metnine www.tparazitolderg.org web sayfasından ulaşılabilir. 


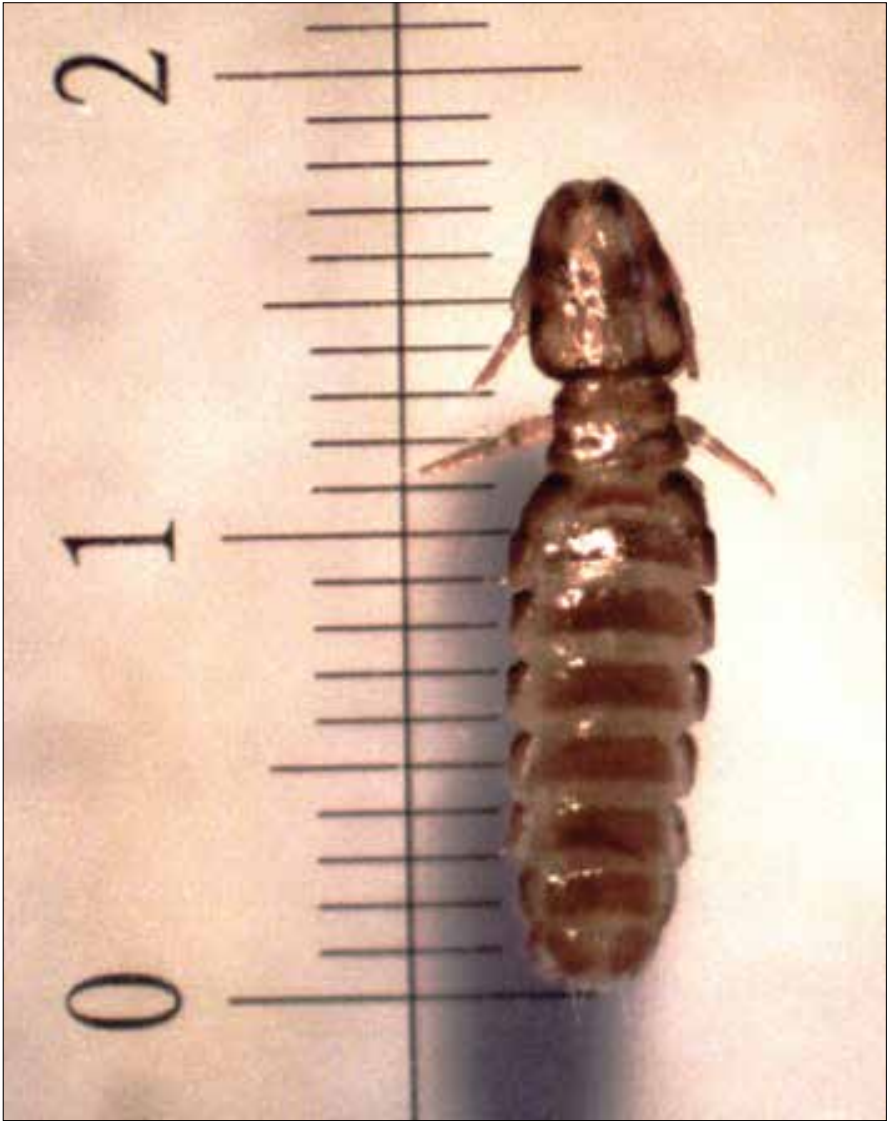

Figure 1. Tricholipeurus balanicus (uncleared): female, dorsal side, original

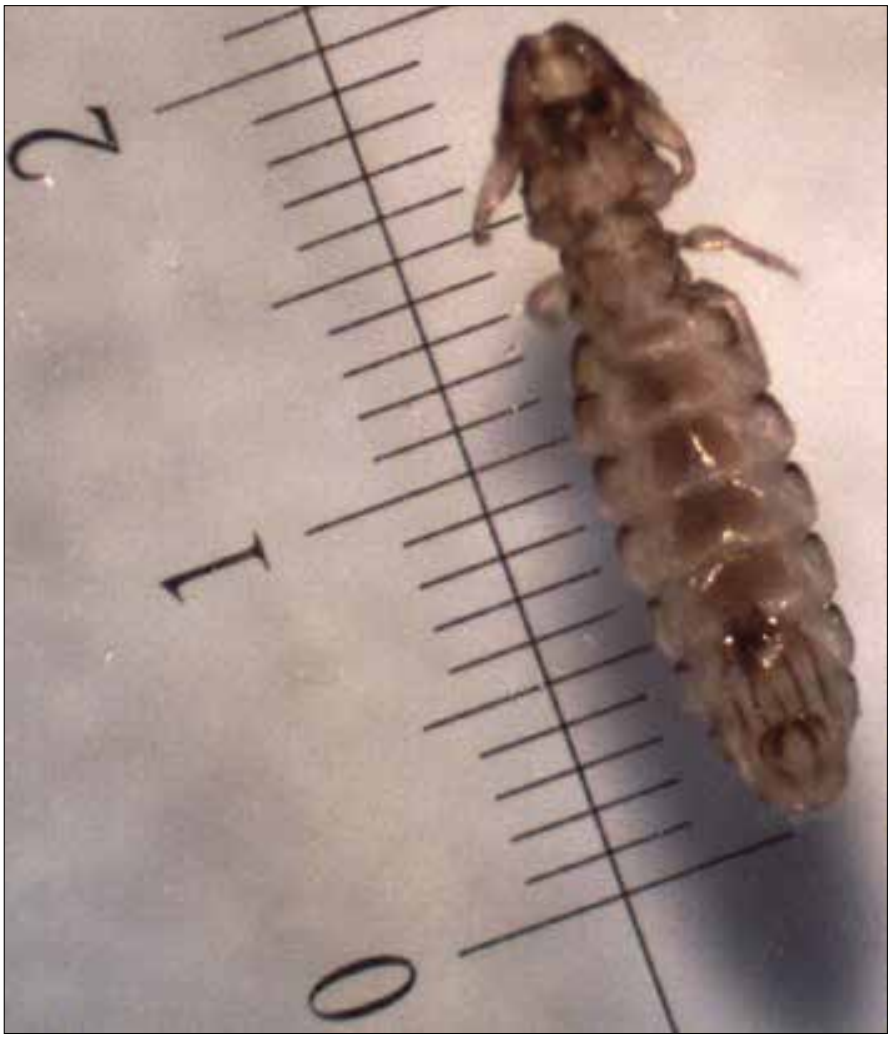

Figure 2. Tricholipeurus balanicus (uncleared): male, original

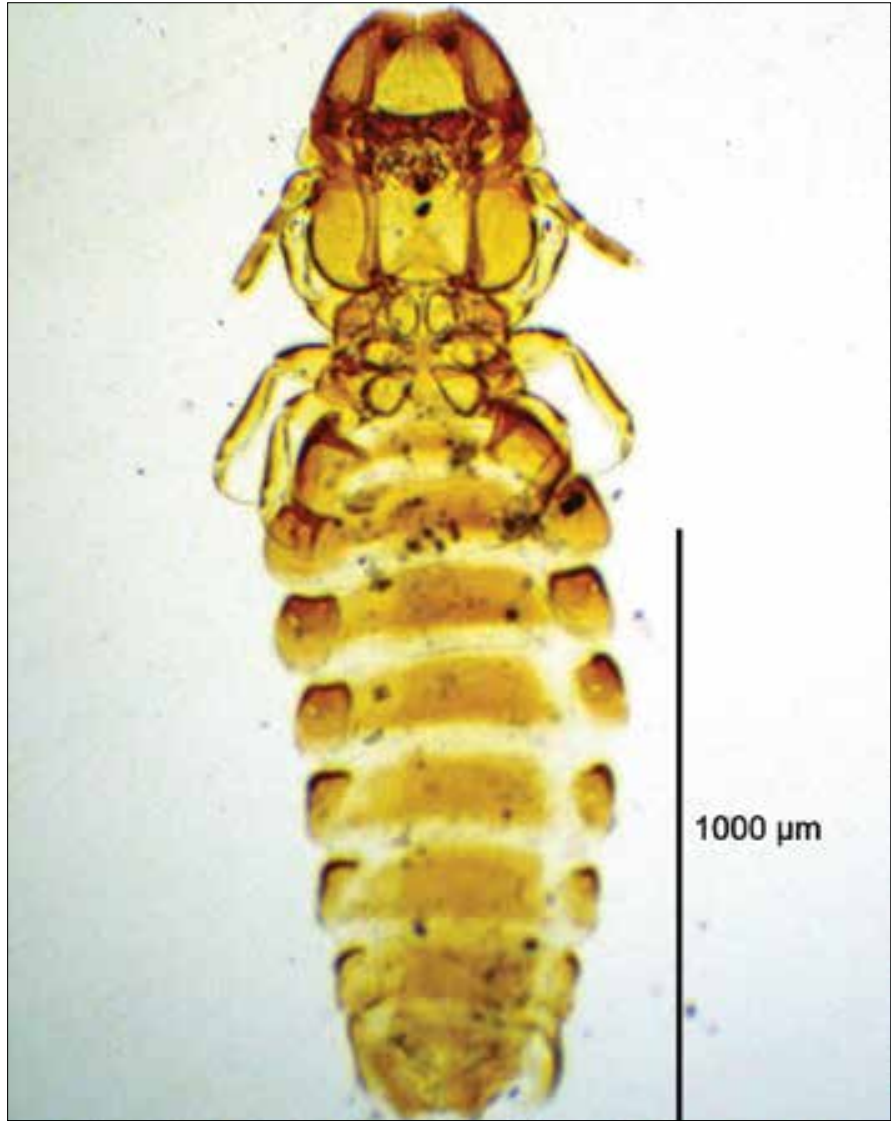

Figure 3. Tricholipeurus balanicus (cleared): female, ventral side, original

slides, examined under a binocular microscope (Leica DM 750), and identified as T. balanicus (Werneck 1938) (Figure 1-8) using relevant literature $(10,12)$.

\section{DISCUSSION}

The species belonging to the genus Tricholipeurus are parasites of Bovidae and Cervidae. Until today, there was no taxonomic key or review on this genus. Similarly to other lice, Tricholipeurus species are host-specific; however, some Tricholipeurus species have been found on other host species of the same or different host genera (14). T. longiceps (Rudow, 1866) is found on the Arabian gazelle ( $G$. arabica), T. cornutus (Gervais, 1844) on the dorcas gazelle (G. dorcas), T. spinifer (Hopkins, 1943) on Grant's gazelle (G. granti), and T. parkeri Hopkins, 1941 on Thompson's gazelle (G. thompsonii) (14), while no Tricholipeurus lice were recorded from slender-horned gazelle, while T. balanicus was described only from the blackbuck (Antilope cervicapra) (10). T. balanicus was found on the blackbuck in Texas, USA (16). There are only few studies on the morphological characteristics of these species $(10,12)$. In our study, 16 males and 14 female and 7 nymphs were measured, and their total lengths were $1.90 \mathrm{~mm}, 1.84 \mathrm{~mm}$, and $1.71 \mathrm{~mm}$, respectively. The total lengths of females in the original description were longer that those of our specimens, while the lengths of males were similar. The head of the female T. balanicus in the original description is anteriorly narrower than that in our samples (Figure 3). In our material, the frontal notch was very shallow, and chitinous plates in the anterior margin were different from the original T. balanicus. 


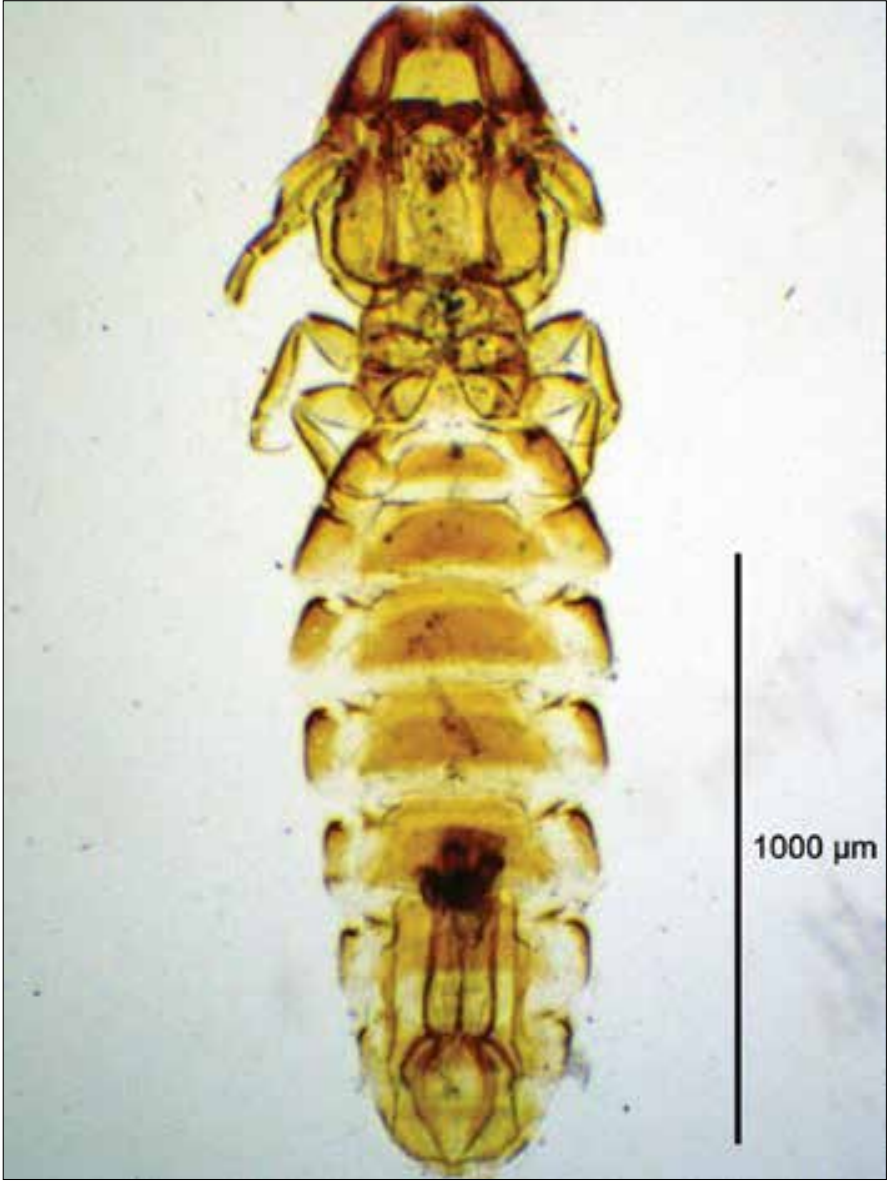

Figure 4. Tricholipeurus balanicus (cleared): male, ventral side, original

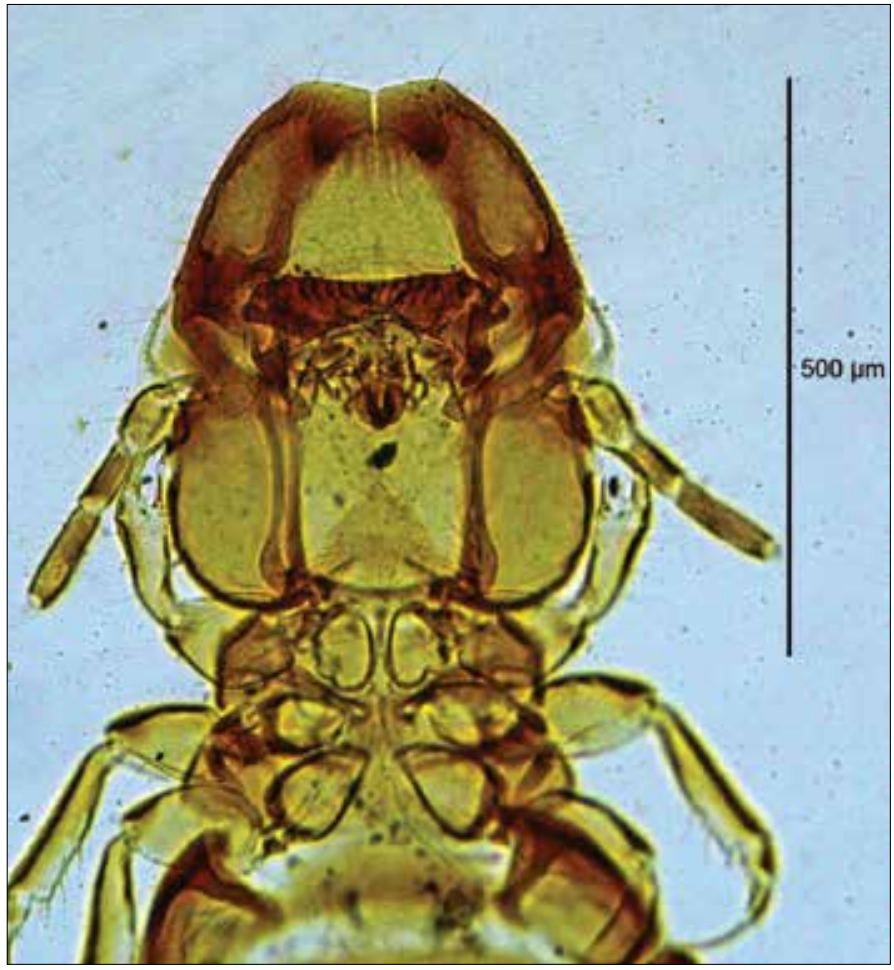

Figure 5. Tricholipeurus balanicus: female, head and thorax, ventral side, original

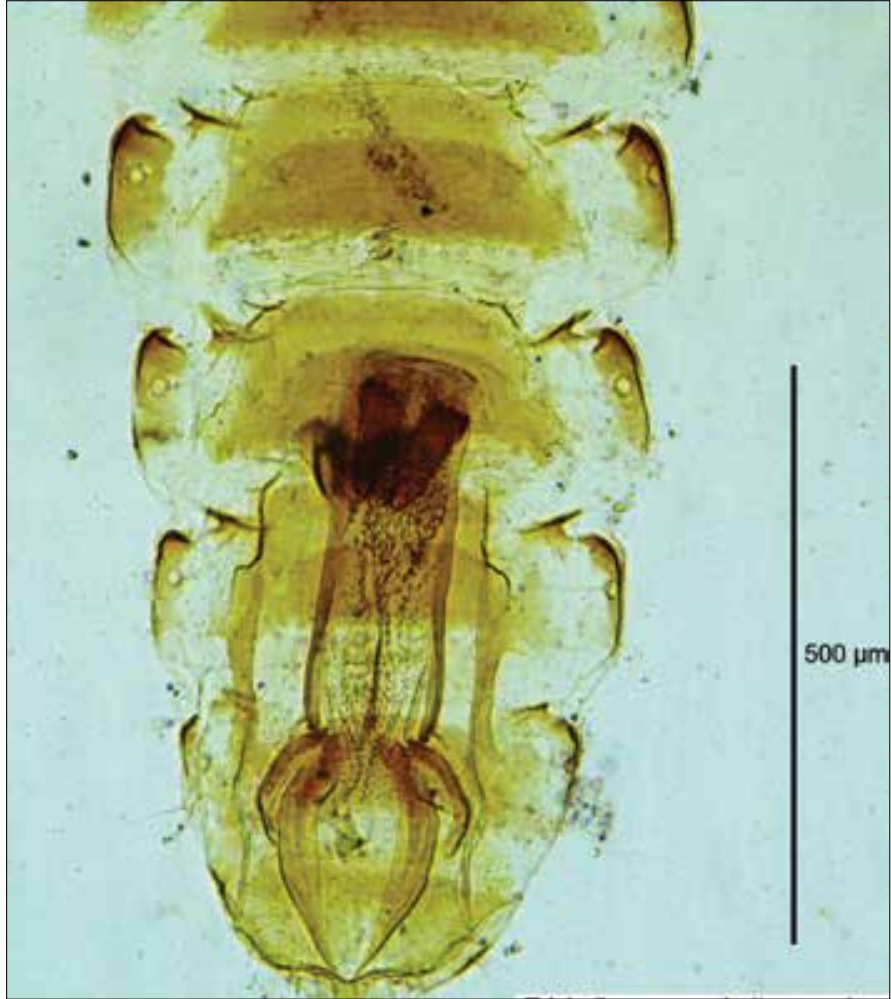

Figure 6. Tricholipeurus balanicus: male genitalia, ventral side, original

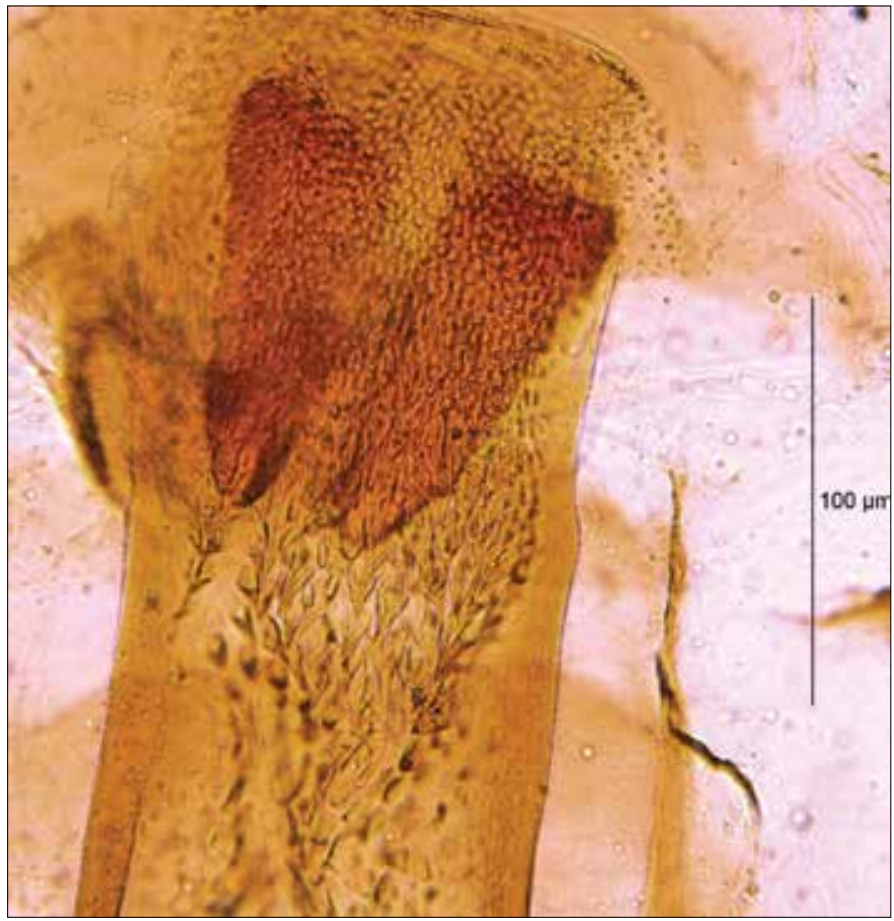

Figure 7. Tricholipeurus balanicus: male genital sac, ventral side original

However, male genitalia and other morphological characteristics were similar with the description and figures of the original work. In our samples, the paramers are more concave than those in Fig. 6 in Werneck's description. Despite these small differences, we consider that our specimens are T. balanicus. 


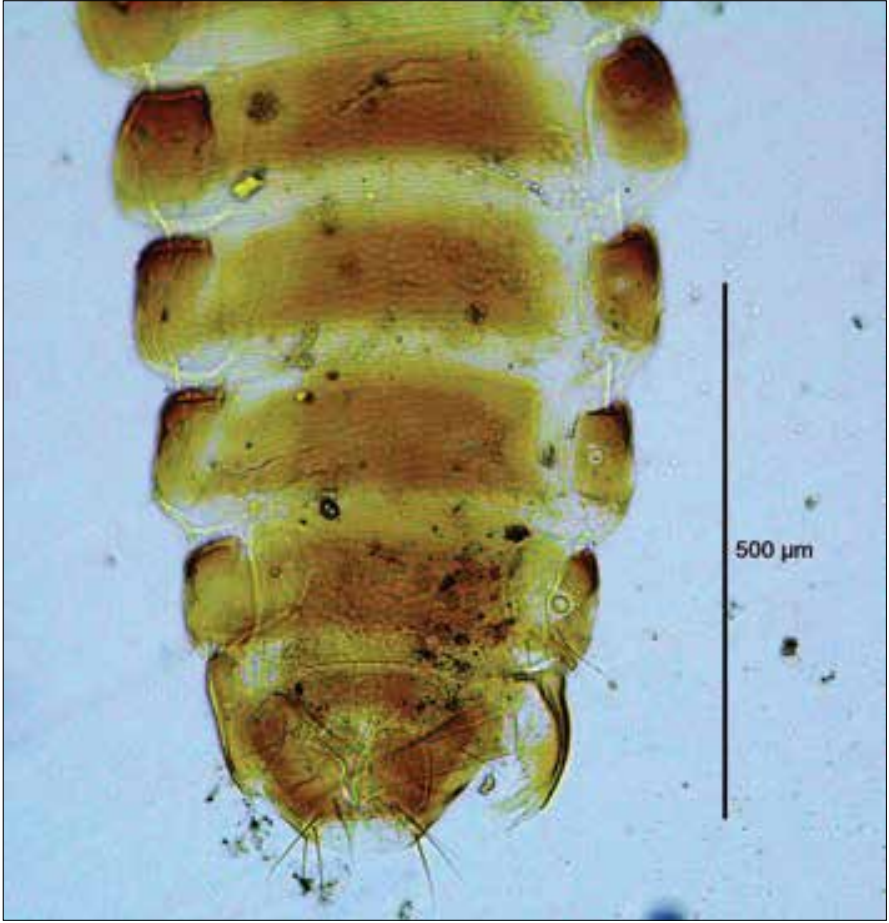

Figure 8. Tricholipeurus balanicus: female, abdomen, ventral side, original

As mentioned above T. balanicus had been described only from the blackbuck; accordingly, the present study is the first report showing that this species can also parasitize the slender-horned gazelle. In the examined zoological garden, there were no blackbucks, and accordingly, it could be not an accidental infestation between the two host species.

\section{CONCLUSION}

T. balanicus was described for the first time on slender-horned gazelle. Further investigations are needed to provide information about the phylogenetic relationship among species and host-parasite associations.

Informed Consent: Not required in this study.

Peer-review: Externally peer-reviewed.

Author Contributions: Concept - B.D., F.M., A.M., H.B.; Design - B.D., F.M., A.M., H.B.; Supervision - B.D., F.M., A.M., H.B.; Funding - B.D., F.M., A.M., H.B.; Materials - F.M., A.M.; Data Collection and/or Processing - F.M., A.M., H.B.; Analysis and/or Interpretation - B.D., F.M., A.M.; Literature Review - B.D., F.M., H.B.; Writing - B.D., F.M.; Critical Review - B.D., F.M., A.M.

Acknowledgements: The authors thank Prof. Dr. Kosta Mumcuoglu for his critical review of the manuscript, and Dr Ricardo L. Palma (Museum of New Zealand, Wellington, New Zealand) for his valuable comments about T. balanicus. We also thank Dr. Khouchane Nouzha, the veterinarian of the El Hamma Zoological Garden and his team.

Conflict of Interest: No conflict of interest was declared by the authors.

Financial Disclosure: The authors declared that this study has received no financial support.
Hasta Onamı: Bu çalışma için gerekli değildir.

Hakem Değerlendirmesi: Dış bağımsız.

Yazar Katkıları: Fikir - B.D., F.M., A.M., H.B.; Tasarım - B.D., F.M., A.M., H.B.; Denetleme - B.D., F.M., A.M., H.B.; Kaynaklar - B.D., F.M., A.M., H.B.; Malzemeler - F.M., A.M.; Veri Toplanması ve/veya İşlemesi - F.M., A.M., H.B.; Analiz ve/veya Yorum - B.D., F.M., A.M.; Literatür Taraması B.D., F.M., H.B.; Yazıyı Yazan - B.D., F.M.; Eleştirel İnceleme - B.D., F.M., A.M.

Teşekkür: Yazarlar, makaleyi değerlendirdiği için Prof. Dr. Kosta Mumcuoğlu'na ve T.balanicus ile ilgili değerli yorumları için Dr. Ricardo L. Palma'ya (Yeni Zelanda Müzesi, Wellington, Yeni Zelanda) teşekkür ederler. Ayrıca, El Hamma Hayvanat Bahçesi'nin veterineri Dr. Khouchane Nouzha ve takımına da teşekkür ederler.

Çıkar Çatışması: Yazarlar çıkar çatışması bildirmemişlerdir.

Finansal Destek: Yazarlar bu çalışma için finansal destek almadığını belirtmiştir.

\section{REFERENCES}

1. Aulagnier S, Haffner P, Mitchel-Jones AJ, Moutou F, Zima J. Guide des Mammifères d'Europe, d'Afrique du Nord et du Moyen-Orient. Ed. Delachaux\&Niestlé, Paris, 2010; p. 27.

2. Kingdon J. The Kingdon Field Guide to African Mammals. Academic Press, London and New York: Natural World; 1997.

3. O'regan BP. Gazelles and dwarf antelopes. Ed. The Encyclopaedia of Mammals. 2, London; 1984.

4. Wilson RT. Ecophysiology of the Camelidae and Desert Ruminants. Springer-Verlag, Heidelberg; 1989. [CrossRef]

5. Bedford GAH. Anoplura (Siphunculata and Mallophaga) from South African Hosts. Ann Rept Dir Veter Serv \& Anim Ind, Union So Africa 1929; 15: 501-49

6. Bedford GAH. New genera and species of Mallophaga. Ann Rept Dir Veter Serv \& Anim Ind, Union So Africa 1931; 17: 283-97.

7. Bedford GAH. Descriptions of new species of Anoplura parasitic on antelopes and a hare. Onderstepoort Journal Veterinary Science and Animal Industry 1934; 2: 41-8.

8. Hopkins GHE. A new East African Tricholipeurus. J East Africa and Uganda Nat Hist Soc 1941; 16: 46-53.

9. Hopkins GHE. Notes on Trichodectidae (Mallophaga). Rev Brasil Biol 1943; 3: 11-28

10. Werneck FL. Algumas species novas de Mallophaga (Trichodectidae). Mem Inst Oswaldo Cruz 1938; 33: 413-22. [CrossRef]

11. Werneck FL. Um novo Malófago de Antilope. Rev Brasil Biol 1947; 7 : 101-5.

12. Werneck FL. Os Malófagos de Mamíferos. Part II. Ischnocera (continuação de Trichodectidae) e Rhynchophthirine. Inst Oswaldo Cruz, Rio de Janeiro, 1950.

13. Werneck FL. A respeitode alguns Malófagos de mamíferos. Rev Brasil Biol 1957; 17: 557-62.

14. Price RD, Hellenthal RA, Palma RL, Johnson KP, Clayton DH. The Chewing Lice 2003. World checklist and biological overview. Illinois Natural History Survey Special Publication; 2003; 24.pp. x + p. 501.

15. Ledger JA. The arthropod parasites of vertebrates in Africa South of the Sahara. Volume IV. Phthiraptera (Insecta). Pub So African Inst Med Res 1980: 56.

16. Wright FC. Tricholipeurus balanicus balanicus (Werneck, 1938) (Mallophaga, Trichodectidae) on Blackbuck Antelope (Antilope cervicapra L.) in Texas. J Wildlife Dis 1985; 21: 68.[CrossRef] 